\title{
Deconstructing Non-Native English-Speaking Teachers' Professional Identity: Looking Through a Hybrid Lens
}

\author{
Nshid Nigar ${ }^{1} \&$ Alex Kostogriz ${ }^{1}$ \\ ${ }^{1}$ Faculty of Education, Monash University, Melboure, Australia \\ Correspondence: Nashid Nigar, Faculty of Education, Monash University, Melboure, Australia.
}

Received: October 5, 2019 Accepted: November 12, 2019 Online Published: November 16, 2019

doi: 10.5539/elt.v12n12p76 URL: https://doi.org/10.5539/elt.v12n12p76

\begin{abstract}
This article critically analyses how the construct of non-native English-speaking teachers' (NNESTs) professional identity has evolved in the context of binary logic and power relations. From a socio-historical point of view, colonial origin of English language teaching and native speaker ideology have been identified as prominent discursive influences of NNESTs' professional identity. Although influenced by (post)colonial discourses, research into NNESTs' professional identity is now veering off to a new direction that questions the binary logic and explores experiences beyond the boundary between the native self and the non-native other. This paper argues that nativeness and non-nativeness are not mutually exclusive and objective categories for NNESTs' professional identity. Their identity is rather subject to constant innovation and plasticity. Beyond the critical analysis of the native speaker construct, the paper proposes a professional conceptualisation of a hybrid professional identity of NNESTs in a third space of reflection, enunciation and productive articulation.
\end{abstract}

Keywords: NNEST, professional identity, third space, hybridity, NEST/NNEST, dichotomy

\section{Introduction}

Before migrating to Australia, I would view the function of English as pragmatic, neutral and natural. But more than a decade ago, when I migrated to Australia and was looking for a job in the English as a Second Language (ESL) field, I realised the need for a critical perspective on the Teaching English as a Second Language (TESOL) field. I experienced the wide spread dominance of the native-speaker concept in Australian ESL teaching domain and could relate to its socio-cultural and institutionalised politics as English is associated with the economic, ideological, socio-political and cultural connections and ramifications (Pennycook, 1995, 2007; R. Phillipson, 1992a; Shin, 2006). In almost every advertised ESL job, being a native speaker of English was a key selection criterion. A handful jobs advertisements of ESL job, which did not have the criterion, I applied for resulted in non-response from the recruiters as the hiring and workplace practices is severely influenced by the native speaker (NS) construct (Braine, 1999; Clark \& Paran, 2007; Flynn \& Gulikers, 2001; Mahboob \& Golden, 2013; Selvi, 2010). This NS "construct" (e.g., Amin, 2001) not only positions the native speaker as the owner and protector of English around the globe (Widdowson, 1994) but also as the universal model of English language to be emulated. All the facets of ELT (English Language Teaching) profession - theory, research, publishing, instructional materials, assessment, teacher training and hiring practices - have pervasively been influenced by a native-speaker construct (Braine, 2010; Canagarajah, 1999b; Jenkins, 2006a; Kachru, 1986, 2006; Leung, 2005). The western culture characterised by this construct represents English Language and its teaching methodology (Holliday, 2005, 2008). In the ELT field, NS (Native Speaker) has been often represented as white, often male and Western in the ELT field, too (e.g., Kubota \& Fujimoto, 2013). Thus, it has been legitimised as a regime of truth (Foucault, 1984) wherein a self-chosen group of elites (Widdowson, 2003) has been benefitted and privileged as scholars and teachers.

\section{1 'Native-speaker' in Colonial Discourses}

The origin of the native speaker construct can be traced back to English Language Teaching (ELT) in British colonies (Pennycook, 1994). In a systematic operation, the western culture, knowledge, language, values, ethics and intellect were and are still generally conceived superior to those of the colonial subjects (Kachru, 1985; Pennycook, 2008). Said (1985) named this as orientalism - "the discipline by which the orient was (and is) approached systematically, as a topic of learning, discovery and practice" (p. 73). Orientalism created a wide distinction between the inferior orient and the superior west. Similarly, the colonial history of English education 
contributed greatly to many currently held ELT tenets, such as "English is best taught monolingually; the ideal teacher of English is a native speaker; the earlier English is taught, the better the results; the more English is taught the better the results; and if other languages are used much, standards of English will drop" (Phillipson, 1992a, p. 185). These tenets have been critically analysed and re-presented as five fallacies in language education that prioritize monolingualism, native speaker, early start, maximum exposure to target language and subtractive model of language education. Phillipson (1992a) further notes that, besides teaching English in (post)colonial contexts, the influence of these tenets is also prevalent in English-speaking countries - USA, UK, Australia, Canada, New Zealand. Institutions like the British Council has played a significant role in normalising the key tenets of ELT globally.

Through the English teaching activities underlying the key tenets, the British Council - originally named as British Committee for Relations with Other Countries - founded in 1934, has acted as the gatekeeper to English as a power tool and linguistic and cultural disseminator (Pennycook, 1994; Phillipson, 1992b). In October 1946, it also set up English language teaching professional standards and the first academic journal - ELT Journal - to promote English and its widespread practices (Phillipson, 1992a). This project has been amplified by other practices, ranging from the "discourses of pre-Second World War 'cultural propaganda' through the post-war discourses on English language teaching as 'development aid', to the more recent understanding of English as a 'global commodity" (Pennycook, 1994, p. 146). Phillipson (1992a) argues that the Council now has a neo-imperialistic agenda. It is now running English language teaching, examinations and assessment business worldwide (Phillipson, 2016), which perpetuates the inequality in the global context of ELT.

\section{Native-speakerism and the Uses of English}

Holliday (2006) calls native-speakerism as a "divisive force" (p. 385) and the "'native speaker' ideal plays a widespread and complex iconic role outside as well as inside the English-speaking West" (p. 385). Although English in the globalised world has diverse uses, users and settings where it is used for a multifarious global end, native-speakerism still dominates the global Englishes. Kramsch (2016) argues that declaring the death of the native speaker 30 years ago (Paikeday, 1986) was premature. The construct is evidently present in the global ELT today. Native speaker teachers are still the mostly desired despite their irrelevance in today's globalised contexts where many of the multilinguals routinely communicate with native speakers and other fellow multilinguals (Kirpatrick, 2016) and their discussion topics and values are rather of specific contexts and cultures, not only the Anglo cultures of native speakers. Kirkpatrick (2016) suggests "in today's multilingual world, multilinguals with multicultural experience are more likely to prove effective language teachers than monolinguals with little cross-cultural experience" (p. 241). Likewise, Kramsch (2016) believes that the so-called "linguistic purity and cultural authenticity" (p. 244) is still in use as a commodity in the job market and a source of symbolic capital (Bourdieu, 2011). For example, NESTs are often offered higher pay and better working conditions than local teachers of English (Braine, 1999; Canagarajah, 1999b; Kiczkowiak, 2014; Mahboob \& Golden, 2013). Moreover, many Australians teach English in Asia without any formal qualifications or experience (Wibawa \& Xiao, 2018). Solely based on the colour of their skin (Kubota \& Fujimoto, 2013) and birth rights in inner circle countries (Kachru, 1986), the privileges of native speakers are reinforced institutionally when they go abroad to study, travel or work. For example, native speaking English teachers (NESTs) are being offered higher pay and better working conditions as compared to the local teachers of English in many countries (Braine, 1999; Canagarajah, 1999b). Many of them can even teach English without any formal qualifications and relevant experience. This practice, solely based on birthrights or the colour of their skin, is "a major source of prejudice and discrimination" (Kirpatrick, 2016, p. 244). It presents native speakers as the ideal English speakers and the best model in teaching English. Although the native speaker model has recently been questioned in the global English language field due to the diversity of Englishes in the world, there are still multiple barriers to eradicating "the epistemic dependence on native English and the native English speaker" (Galloway \& Rose, 2015, section heading. Chapter Summary).

\section{1 'Native-speaker' in Linguistics}

As a cognitive system, the term 'native speaker' was first used in Chomsky's linguistic theory. Native speakers, according to Chomsky (1965), are those who can intuitively judge the validity of their languages and identify grammatical errors in their languages although they may not be able to explain explicitly why the errors are made. His theory is based on "an ideal speaker listener in a completely homogeneous speech community, who knows its language perfectly and is unaffected by such grammatically irrelevant conditions as memory limitations, distractions, shifts of attention and interest, and errors (random or characteristic) in applying his knowledge of the language in actual performance" (Chomsky, 1965, p. 3). This construct of idealised native speaker-hearer has been widely used in the second language acquisition (SLA) field. As Bhatt (2002) states: 
Most of the constructs used in second language acquisition (SLA) theories, especially the cognitivist approaches, derive their meaning from the epistemology and methodology of the Chomskyan paradigm - the study of language as a cognitive system. Leading experts in the SLA field, such as Coder (1967, 1973), Selinker (1972) and Dulay, Burt and Krashen (1982), embraced this view uncritically. (p. 80)

This cognitively oriented SLA research sets native speaker as the ideal speaker of English and stereotypes the non-native speaker as a "defective communicator, limited by an underdeveloped communicative competence" (Firth \& Wagner, 1997, p. 285). Selinker (1972) coined the terms target language, interlanguage and fossilisation. Interlanguage is "...the linguistic system characterizing the output of a non-native speaker at any stage prior to full acquisition of the target language" (p. 995) and fossilisation is "... to become permanently established in the interlanguage of a second-language learner in a form that is deviant from the target-language norm and that continues to appear in performance regardless of further exposure to the target language" (p. 775). The native-speaker model has been given absolute authority by these terms in SLA and, hence, both English language learning and non-native speakers have been viewed from a deficit perspective (Mahboob, 2005). As a result, the following axioms have been established in TESOL and applied linguistics: 1) there is a standard language that provides access to knowledge; 2) only those few who speak the standard language can command linguistic authority over non-standard speakers; and 3) myth and history are indistinguishable (Bhatt, 2002, pp. 76-77). This hierarchical model of the imagined community of English language users works to sustain the status quo of the so-called Standard English in the world as being inevitably accepted by all the community members.

The native speaker model was questioned first in sociolinguistics. Hymes (1972) states that, while acquiring the native language, a child not only acquires the knowledge of grammatical structures of sentences but also how to use those sentences appropriately in specific contexts: "when to speak, when not, and as to what to talk about with whom, when, where, in what manner" (277). This sociolinguistic perspective on language acquisition is based on the recognition of diverse uses of language in a heterogeneous community of speaker-listeners. It challenges the Chomsky's homogeneous community of ideal speaker and listener model. Since 1990s, both the assumptions around the native speaker and the linguistics theories contributing to the construct have been seriously questioned (e.g., Holliday, 2008; Paikeday, 1986; Phillipson, 1992a, 1992b; Rampton, 1990). Not unlike the given areas, the presence of 'native speaker' is evident in the profession of non-native English-Speaking Teachers (NNEST), too. However, it is important not only to present the native and non-native speaker dichotomy but also to deconstruct it.

\section{3. 'Native Speaker' in NNEST Profession}

The NS construct has also been essentially positioned the native speaking English teachers (NESTs) and non-native English-speaking teachers (NNESTs) in dichotomous binary. NESTs have been regarded as better teachers with an idealised absolute source of knowledge while non-native English-speaking teachers (NNESTs) are labelled as imperfect communicators. This binary categorization damages NNESTs' self-confidence, agency, and their teaching performance (Lowe \& Kiczkowiak, 2016; Reves \& Medgyes, 1994; Samimy \& Brutt-Griffler, 1999); it causes them to constantly experience the "I-am-not-a-native-speaker" (Suárez, 2000, para. 10) or "impostor" syndromes (Bernat, 2008). Due to this construct, they may be negatively judged by themselves, their students, colleagues, administrators and their supervisors (e.g., Amin, 1997; Braine, 2010; Brutt-Griffler \& Samimy, 1999; Canagarajah, 1999b; Matsuda, 2016; Matsuda \& Matsuda, 2001; Maum, 2002, 2003; Moussu, 2002, 2006, 2010; Reves \& Medgyes, 1994; Thomas, 1999). The discourses constantly affect non-native English-speaking teachers' professional selves negatively. They demoralise them and affect psychologically, which makes them struggle to form their professional identity as legitimate TESOL teachers in the very field they belong to (Canagarajah, 1999b; Reis, 2010). The native-speakerism also illegitimately establishes criteria race, nativeness, place of birth, ethnicity - that are irrelevant to English teacher professionalism and English teaching practice.

For example, in Reves and Medgyes' (1994) international study of 216 non-native speaker English teachers, eighty four percent of NNSET participants admitted to having difficulties in English vocabulary, fluency, speaking, pronunciation and listening comprehension. The participants reported that the perpetual fear of their students' judgments made them constantly self-conscious about their mistakes, which lead them to be unconfident in their language performance. Likewise, Canagarajah (1999a; 2005) and Thomas (1999) found that when NNESTs make mistakes or do not know something about the English language, their teaching abilities and efficiencies are often immediately questioned. In another study by Brutt-Griffler and Samimy (1999), seventeen non-native TESOL graduate students felt that unlike EFL contexts, they were regarded neither qualified nor appreciated in ESL context and their competencies were often questioned. In Amin's (1999) study in a Canadian context, five minority immigrant women thought that their students constantly judged and compared them with 
the native and white teachers, positioning them as inferior to the native speaker teachers. Again, ESL participants of Moussu's $(2002,2006)$ studies held negative attitudes towards their NNSETs and would like to be taught by the native speaker teachers at a US university. However, in last two decades, the unwarranted practices have been vehemently resisted by NNEST movement.

\subsection{NNEST Movement and Resistance Against Native-speakerism}

The NNEST movement was the first institutionalised form of resistance against the wrong practices native-speakerism in TESOL. It originated in 1996 at the colloquium "In Their Own Voices: Non-native Speaker Professionals in TESOL" organised by a group of scholars participating in the 30th Annual TESOL Convention held in Chicago (Rudolph, Selvi, \& Yazan, 2015). The first official meeting of the Caucus, formed in 1998, was held at the 1999 TESOL Convention in New York. The overarching goals of the Caucus were:

1) creating a non-discriminatory professional environment for all TESOL members regardless of native language and

place of birth,

2) encouraging the formal and informal gatherings of NNS at TESOL and affiliate conferences,

3) encouraging research and publications on the role of non-native speaker teachers in ESL and EFL contexts, and

4) promoting the role of non-native speaker members in TESOL and affiliate leadership positions.

This institutionalised NNEST entity was voiced in local and international TESOL affiliates, too. Almost twenty years later, the NNEST movement have grown out of its small group of TESOL professionals with their visibility issues within the TESOL International Association. Currently, it encompasses all the non-native English-speaking teachers, practitioners, researchers and administrators all over the world. However, until now not all the goals of the NNEST movement - founded at the time of the caucus - have been achieved. The most disappointing is that the NNEST movement has not been successful in achieving its first caucus goal: to create a non-discriminatory professional environment for all TESOL International Association members regardless of native language and place of birth. Despite these institutionalised initiatives and responses, discriminatory hiring and workplace practices are still ironically present in the ELT profession (Mahboob, 2010; Selvi, 2016). Furthermore, discrimination on the basis based of gender, race, ethnicity, nationality, accent, appearance and/or sexual orientation has been at large both globally and locally (Mahboob \& Golden, 2013).

\subsection{Native-speakerism in Australian TESOL Context}

The fallacy of native-speakerism can be found in Australian English language education policies and government funding provision too. In Australia, relevant to language education and hence ESL profession are two of the major language policies: National Policy on Languages (NPL) (Lo Bianco, 1987) and Australia's Language - the Australian Language and Literacy Policy (ALLP) (DEET, 1991). NPL policy was multilingual whereas the focus of ALLP was rather post-colonial, monolingual - "English for all, and proposed that the main challenge for education is to ensure literacy (in English) for all" (Ellis, 2016, p. 25). Additionally, in 1998, the central funding to the major providers of ESL instruction program for immigrants Adult Migrant Education Program (AMEP) ceased and a new system was introduced: a tender-based competition for funding to run the programs (Burns \& Joyce, 2007). Thus, the privatisation of AMEP program affected "program quality, the meeting of learner needs, the ability of teachers to teach according to their professional judgement, and on teacher salary and conditions" (ACTA, 2014, p. 26). Given the two main language policies influenced a shift of the ESL system in Australia from plurilingual to monolingual, English was taught via the English-only medium by native-speaking teachers.

Historically, ESL education as way of assimilating the displaced people from war-torn Europe in Australia started to develop after World War II (Ellis, 2016). The development of ESL education in Australia at that time was informed by a colonial project of acculturating the other and, in so doing, normalising the otherness and/or inferiority of non-native speakers and thereby producing their desire to master the language norms of middle-class white native speakers (Faine, 2009; Oliver, Rochecouste, \& Nguyen, 2017). However, from the 1970s, multicultural programs were initiated as a necessary means of responding cultural-linguistic diversity and to the flow of refugees from war-torn countries in Asia and the Middle East. Despite a long-term and significant investment in multicultural education in Australia, the ESL/EAL field still remains "a subject to sometimes intermittent and ad hoc funded assistance" (Oliver et al., 2017, p. 1). Because of this historical instability in ESL policy, funding and pedagogy, ESL teachers in Australia have not yet found a solid professional standing that would enable teachers to challenge the hegemony of native speakers in curriculum and pedagogy. 
In ESL course books in Australia, the native speaker construct still dominates the published materials about and for TESOL teachers and students in the global ELT field as well as the Australian context (Ellis, 2016). The non-native English-speaking teachers (NNESTs) in Australia "have often been regarded as second-best to native speaker teachers..., tend to suffer a professional inferiority complex" (Ellis, 2016, p. 30) and are still facing employment discriminations because of the influence of native speaker fallacy (Fotovatian, 2010, 2015). For example, a search for ESL jobs in September 2017 resulted in finding a handful of job advertisements based on native speaker like status. A job advertisement by one of the prominent university English language centres had "excellent communication (both written and spoken English - at either native speaker or IELTS 8+ level) and interpersonal skills" as one of the selection criteria for a casual language teacher (SEEK, 2017, para. 3). Although this position description appeared to be non-discriminatory, as compared to the job search conducted by the first author in 2005, there were still sediments of discriminatory discourses. Non-native English-speaking teachers continue experiencing employment impediments in both ESL and non-ESL areas of teaching. Several studies reported that the Australian ESL professional field is mystified by employers' preference to recruit native speaker teachers (Fotovatian, 2010, 2015). Partly, this is due to regulations and qualifications standards that are based on the normative practice of native speakers.

Qualification standards for ESL teachers in Australia are set by the National ELT Accreditation Scheme (NEAS) - the national accreditation authority for ELT Centres in Australia. It is responsible for the accreditation in both English Language Intensive Course for Overseas Students (ELICOS) and publicly funded centres. Two types of accreditations are for two types of English teachers: private and university ELICOS centre teachers and AMEP teachers. Like that in the UK, in Australia the basic requirement of an ELICOS teacher is a Certificate in English Language Teaching to Adults (CELTA). This is an international qualification moderated by Cambridge English. Teachers in NEAS-endorsed ELT centres are required to hold a recognised degree or equivalent TESOL qualification or a recognised degree in education with TESOL method (NEAS, 2017).

Therefore, to be eligible to teach English in Australia, non-native English-speaking teachers - either new or experienced - undergo assessment and/or re-education. Their prior qualifications and experience in teaching English in their home countries are often not recognized. The teachers have to obtain the second or the third qualification because the recognised TESOL qualification has to be "delivered by an education provider registered with government as being eligible to deliver nationally recognised qualifications" or they have to have a recognised degree in education with TESOL method (NEAS, 2017, NEAS teacher qualifications). The overseas degree of a non-native English speaking teachers should be assessed to confirm "local equivalence" (NEAS, 2017, NEAS teacher qualifications). By default, these qualifications need to be obtained in the countries where English is spoken as the first language because these countries alone are the providers of equivalent courses.

\section{ELT Professional Standardisations Across English Speaking Countries}

ELT professional standards in English-speaking countries often contain normative statements about expected knowledge, skills, attitudes and experience. As such, they do not recognize the value of teacher second language proficiency and, hence, the experience of learning a second language in teaching English to culturally and linguistically diverse students. Equally, standards do not recognize the importance of cultural diversity in the formation of professional identity and how it informs responsive teaching and professional selves. Professional standardisation of ELT, in general, appears to validate and perpetuate of the native speaker fallacy through discourses of standards. For example, the TESOL International Association for language teachers states the native-speaker language proficiency as a benchmark for ESL teachers in Standard 5 together with a higher education qualification (TESOL International Association, 2017). The requirement of having a native like proficiency here undermines the recognition of non-native teachers as professionals, although they can be qualified and experienced language educators.

Equally, the professional standards for EAL/D teachers in the Australian context continue to be informed by discourses of native speakerism. These standards were formulated in 2015 to align with the Australian professional standards for teachers (APST) and to standardise knowledge and practice of EAL/D teachers (ACTA, 2015). Standard 2 on knowing the content and how to teach it mandates all EAL/D teachers to "understand the features of Standard Australian English, the language-and-culture demands of curriculum and community, and how to teach these as EAL/D content whether as an integrated part of mainstream teaching or as the focus of EAL/D classes" (ACTA, 2015, EAL/D Elaborations of the Australian Professioanl Standards for Teachers). By the requirement of understanding and teaching the features of the Standard Australian English, this statement delegitimizes the non-native teachers of English who have accents or are the users of world Englishes. 


\section{Re-formulating Native-speakerism and the NESTs and NNESTs Divide}

From a critical perspective, native speakerism is no longer an ideology that just benefits the native speakers and marginalises the non-native speakers. Scholars argue that native speakerism is challenged as an ideology that has so far used stereotypes and prejudices to label people as superior or inferior as per their affiliation or non-affiliation to the native speaker category (Holliday, 2015; Houghton \& Rivers, 2013a). Like race, native speaker-hood is not a biological endowment, but is rather a social construct (Faez, 2011; Piller, 2002). The other social and contextual factors may be responsible for the practice of this ideology, such as gender, race, ethnicity, nationality, accent, appearance and/or sexual orientation (Holliday, 2015; Mahboob \& Golden, 2013; Selvi, 2010). From a sociolinguistic perspective, Faez (2011) and Piller (2002) argue that the native - non-native dichotomy is a misrepresentation. Binaries in the construction of linguistic identities are "constantly evolving and adapting social perceptions rather than ... mutually exclusive objective categories that provide valuable insights about individuals or their language practices" (Aneja, 2016b, p. 573). These two labels are neither objective nor value free but rather subjective and politically driven (Holliday, 2013, 2015).

Therefore, critical approaches to ELT challenge the native speaker construct and its wide-spread impact on ELT because of practical uses of English globally (Canagarajah, 2007; Firth \& Wagner, 1997; Jenkins, 2006a; Kachru, 1986; Kirpatrick, 2016; Kramsch, 2016; Lipovsky \& Mahboob, 2010; Mahboob, 2010; Matsuda, 2016; Norton, 2015; Pennycook, 1994; Phillipson, 1992b; Widdowson, 2003). They add extra attention to the power struggle of non-native English-speaking teachers (NNEST) for recognition and equal rights. Scholars have also problematised "the use of critically oriented binaries and argue for a reconsideration of the nature and location of "inside" and "outside" and "us" and "them" (Rudolph et al., 2015, p. 29) because the binary logic fails to capture how NNESTs' experiences are translated and negotiated in spaces of hybridity where binaries and differences collide. Any form of essentialisation also obfuscates the creative identity work and multilingual, intercultural, transcultural, trans-linguistic experiences of people (Mahboob, 2010; Menard-Warwick, 2008; Motha, Jain, \& Tecle, 2012; Park, 2012; Rudolph, 2012)

Rather than essentialising identities, hybridity embraces in-between-ness and border-crossings and, in doing so, is about discontinuity and disorganisation of hegemonic discourses and practices (Bhabha, 1994, 1996). This third space is not merely a subjective space of reflection but a mode of enunciation, a way of dynamic and productive articulation of becoming an English teacher beyond a native - non-native divide. Bhabha calls this "interruptive, interrogative, and enunciative" process (Bhabha, 1994, p. 30) that creates novel cultural variations, calling the long held binary practices of culture and identity into question. This is an equivocal site that does not have any inherent harmony or constancy. In spite of the ambivalent nature of the third space, it introduces spatial inclusiveness by initiating "new signs of identity, and innovative sites of collaboration and contestation" (Bhabha, 1994, p. 1). Contrary to the coloniser's normalisation of nativeness as a hegemonic practice, hybridity initiates a third space of/for rearticulation of new meanings. Such a novel space of identity-making positions NNESTs in between the native - non-native binary and destabilises the deeply rooted power relations.

The third space for the non-native speaking English speakers may work as a site for the construction of globally situated and multilingual identity. It may impact the teachers' practices, opening them to diverse life histories and teaching philosophies (Motha et al., 2012; Pennycook, 2004). Such teaching practices may be attentive to discourses and interactions both in and outside classrooms and invite students to question racial privileges and accent hierarchies in English teaching. This may result in a resistance to discriminatory discourses and prejudices. While facing injustices, one of the strategies non-native English-speaking teachers can be reclaiming English as Englishes with multiple accents and varieties. In doing so, teachers may challenge the professional identity that disqualifies them on the bases of their accents or race and/or nativeness (e.g., Motha et al., 2012; Thomas, 1999). This strategy could be employed by being engaged into institutional and classroom discourses and debates. A teacher can also be involved in performative acts of building intercultural bridges (Bardhan, 2012) which can act as a teaching tool for the students' own lives. This is because non-native teachers share experiences with their students.

These discursive practices and interactions can enhance knowledge and meaning production and create a community of language learners (Lave \& Wenger, 1991; Vygotsky, 1978). Instead of English only classrooms, such a community of language learners can be built by encouraging the trans-linguistic practices of students. This can be used in today's English classrooms as a pedagogical tool for recognising and celebrating the multi-lingual identities of NNESTs and their students. Teachers in such classrooms can demystify prejudices of the native-speaker construct and help students develop their own agency in speaking back to the discourse that produce deficit positions for their linguistic and socio-cultural identities. The teacher may need to embrace in this case a Dubois style (1903/2006) "double-consciousness" (Motha et al., 2012, p. 21); as one who positions 
herself strategically and pragmatically on and across racial, linguistic and cultural borders. As Motha et al. (2012) put this, "our teaching practices are informed by our life histories and... our identities impact our pedagogies, we as educators can strategically position ourselves to tap into identities as a pedagogical resource" (p. 13).

\section{Conclusion}

To date, research into non-native English-speaking teachers has predominantly addressed the areas relating to the binary categorisation perspectives, be it native and non- native teacher related issues, or, their self- perceptions, the perceptions of students, administrators and others about NNESTs as legitimate speakers and users of language. But a more recent hybrid perspective on teacher identity has refocused our attention to a more dynamic and fluid conceptualization of both professional identity and practice. The studies of hybridity have explored how individual teachers' personal and professional identities have been negotiated experientially and relationally in various socio-cultural settings. As Pennycook (1999) points out, critical approaches to TESOL have a transformative potential to break through the walls constructed by binary logic and relations of power. The third space of professional identity- and practice-creation can be a response to the marginalization of NNESTs by discourses that disqualify and misrecognise their professional selves and teaching experiences. Third space can be also used in conceptualising new learning environments in which both teachers and students can draw on multiple cultural and linguistic resources and, in turn.

\section{References}

ACTA. (2014). AMEP Evaluation Skills for Education and Employment Evaluation. Retrieved from http://www.tesol.org.au/files/files/496_AMEP_SEE_Program_Evaluation_2014_-_ACTA_Response.pdf

ACTA. (2015). EAL/D Elaborations of the Australian Professional Standards for Teachers. Retrieved from http://tesol.org.au/files/files/530_60238_EALD_elaborations-Short_Version_Complete.pdf

Amin, N. (1997). Race and the Identity of the Nonnative ESL Teacher. Tesol Quarterly, 31(3), 580-583. https://doi.org/10.2307/3587841

Amin, N. (1999). Minority women teachers of ESL: Negotiating white English. Non-native educators in English language teaching, 93-104.

Amin, N. (2001). Nativism, the native speaker construct, and minority immigrant women teachers of English as a second language. CATESOL Journal, 13(1), 89-107.

Aneja, G. (2016a). Rethinking Nativeness: Toward a Dynamic Paradigm of (Non)Native Speakering. Critical Inquiry in Language Studies, 13(4), 351-379. https://doi.org/10.1080/15427587.2016.1185373

Aneja, G. (2016b). (Non)native Speakered: Rethinking (Non)nativeness and Teacher Identity in TESOL Teacher Education. Tesol Quarterly, 3, 572. https://doi.org/10.1002/tesq.315

Bardhan, N. (2012). Postcolonial migrant identities and the case for strategic hybridity: Toward "inter" cultural bridgework. In N. Bardhan, \& M. P. Orbe (Eds.), Identity research and communication: Intercultural reflections and future directions (pp. 149-164). Lanham, MD: Lexington Books.

Bernat, E. (2008). Towards a pedagogy of empowerment: The case of 'impostor syndrome'among pre-service non-native speaker teachers in TESOL. English language teacher education and development, 11(1), 1-8.

Bhabha, H. (1994). The Location of Culture. London and New York : Routledge.

Bhabha, H. (1996). Culture's in-between. In S. Hall, \& P. Du Gay (Eds.), Questions of cultural identity (pp. 53-60). London: SAGE. https://doi.org/10.4135/9781446221907.n4

Bhatt, R. M. (2002). Experts, dialects, and discourse. International Journal of Applied Linguistics, 12(1), 74-109. https://doi.org/10.1111/1473-4192.00025

Bourdieu, P. (2011). The forms of capital. Cultural theory: An anthology, 1, 81-93.

Braine, G. (1999). Non-native educators in English language teaching. Mahwah, N.J.: L. Erlbaum Associates.

Braine, G. (2010). Non-native-speaker English teachers. New York: Routledge. https://doi.org/10.4324/ 9780203856710

Brutt-Griffler, J., \& Samimy, K. K. (1999). Revisiting the colonial in the postcolonial: critical praxis for nonnative-English-speaking teachers in a TESOL program. Tesol Quarterly, 33(3), 413-431. https://doi.org/10.2307/3587672

Brutt-Griffler, J., \& Samimy, K. K. (2001). Transcending the nativeness paradigm. World Englishes, 20(1), 99-106. https://doi.org/10.1111/1467-971X.00199 
Burns, A., \& Joyce, H. (2007). Adult ESL programs in Australia. Prospect, 22(3), 5-17.

Canagarajah, A. S. (1999a). Resisting linguistic imperialism in English teaching. UK: Oxford University Press.

Canagarajah, A. S. (1999b). Interrogating the "native speaker fallacy": Non-linguistic roots, non-pedagogical results. In G. Braine (Ed.), Non-native educators in English language teaching (pp. 77-92). Mahwah, N.J.: L. Erlbaum Associates.

Canagarajah, A. S. (2005). Reclaiming the Local in Language Policy and Practice. Mahwah: Mahwah: Lawrence Erlbaum Associates.

Canagarajah, A. S. (2007). Lingua Franca English, Multilingual Communities, and Language Acquisition. Modern Language Journal, 91(5), 923-939. https://doi.org/10.1111/j.1540-4781.2007.00678.x

Chomsky, N. (1965). Aspects ofthe theory ofsyntax. Cambridge, MA: MIT Press.

Clark, E., \& Paran, A. (2007). The employability of non-native-speaker teachers of EFL: A UK survey. System, 35(4), 407-430. https://doi.org/10.1016/j.system.2007.05.002

DEET (1991). Australia's Language: The Australian Language and Literacy Policy: Companion Volume to the Policy Information Paper, August 1991. Canberra: Australian Government Publishing Service.

Ellis, E. (2002). Teaching from experience: a new perspective on the non- native teacher in adult ESL. Australian Review of Applied Linguistics, 25(1), 71-107. https://doi.org/10.1075/aral.25.1.05ell

Ellis, E. (2016). The TESOL profession as a monolingual monolith. In The plurilingual TESOL Teacher: The hidden languaged lives of TESOL teachers and why they matter. de Gruyter Mouton. Berlin and New York: De Gruyter. https://doi.org/10.1515/9781614513421

Faez, F. (2011). Reconceptualizing the native/nonnative speaker dichotomy. Journal of Language, Identity \& Education, 10(4), 231-249. https://doi.org/10.1080/15348458.2011.598127

Faine, M. (2009). At home in Australia: identity, nation and the teaching of English as a second language to adult immigrants in Australia. Monash University. Faculty of Education.

Firth, A., \& Wagner, J. (1997). On discourse, communication, and (some) fundamental concepts in SLA research. The Modern Language Journal, 81(3), 285-300. https://doi.org/10.1111/j.1540-4781.1997.tb05480.x

Flynn, K., \& Gulikers, G. (2001). Issues in hiring nonnative English-speaking professionals to teach English as a second language. CATESOL Journal, 13(1), 151-161.

Fotovatian, S. (2010). Surviving as an English Teacher in the West: A Case Study of Iranian English Teachers in Australia. TESL-EJ, 13(4), n4.

Fotovatian, S. (2015). Language, institutional identity and integration: Lived experiences of ESL teachers in Australia. Globalisation, Societies and Education, 13(2), 230-245. https://doi.org/10.1080/14767724.2014. 934072

Foucault, M. (1984). The Foucault reader (ed. P. Rabinow). New York: Pantheon.

Galloway, N., \& Rose, H. (2015). Introducing Global Englishes. https://doi.org/10.4324/9781315734347

Holliday, A. (2005). The struggle to teach English as an international language. Oxford: Oxford University Press.

Holliday, A. (2006). Native-speakerism. ELT Journal, 60(4), 385-387. https://doi.org/10.1093/elt/ccl030

Holliday, A. (2008). Standards of English and politics of inclusion. Language Teaching, 41(01), 119-130. https://doi.org/10.1017/S0261444807004776

Holliday, A. (2013). "Native speaker" teachers and cultural belief. In S. Houghton, \& D. J. Rivers (Eds.), Intergroup dynamics in foreign language education (pp. 17-27). Bristol: Multilingual Matters. https://doi.org/10.21832/9781847698704-005

Holliday, A. (2015). Native-speakerism: taking the concept forward and achieving cultural belief. In A. Swan, P. Aboshiha, \& A. Holliday (Eds.), (En)Countering nativespeakerism (pp. 11-25). New York, NY: Palgrave Macmillan. https://doi.org/10.1057/9781137463500_2

Houghton, S., \& Rivers, D. J. (2013a). Introduction: Redefining native-speakerism. In S. Houghton, \& D. J. Rivers (Eds.), Native-speakerism in Japan. Intergroup dynamics in foreign language education (pp. 1-16). Bristol: Multilingual Matters. 
Hymes, D. H. (1972b). On communicative competence. In J. B. Pride, \& J. Holmes (Eds.), Sociolinguistics (pp. 269-293). Harmondsworth, England: Penguin.

Jenkins, J. (2006a). Current Perspectives on Teaching World Englishes and English as a Lingua Franca. TESOL Quarterly: A Journal for Teachers of English to Speakers of Other Languages and of Standard English as a Second Dialect, 40(1), 157-181. https://doi.org/10.2307/40264515

Kachru, B. (1985). Institutionalized second language varieties. The English Language Today, 211-226.

Kachru, B. (1986). The alchemy of English : the spread, functions, and models of non-native Englishes (1st ed. ed.). Oxford [Oxfordshire]New York: Oxford Oxfordshire

Kachru, B. (2006). The English language in the outer circle. World Englishes, 3, 241-255. https://doi.org/10.1016/B0-08-044854-2/00645-3

Kiczkowiak, M. (2014). Native English-speaking teachers: always the right choice? Retrieved from https://www.britishcouncil.org/voices-magazine/native-english-speaking-teachersalwaysright-choice

Kirpatrick, A. (2016). Just because I'm a native speaker. In S. G. a. S. M. Fiona Copland (Ed.), LETs and NESTs: Voices, Views and Vignettes (pp. 241-242). UK: British Council.

Kramsch, C. (2016). Native-speakerism in language teaching. In S. G. a. S. M. In Fiona Copland (Ed.), LETs and NESTs: Voices, Views and Vignettes (pp. 246-247). UK: British Council.

Kubota, R., \& Fujimoto, D. (2013). Racialized native speakers: Voices of Japanese American English language professionals. In H. D. J. Rivers (Ed.), Native-Speakerism in Japan: Intergroup dynamics in foreign language education (pp. 196-206). Bristol: Multilingual Matters. https://doi.org/10.21832/978184769 8704-018

Lave, J., \& Wenger, E. (1991). Situated learning: Legitimate peripheral participation: Cambridge university press. https://doi.org/10.1017/CBO9780511815355

Leung, C. (2005). Convivial communication: Recontextualizing communicative competence. International Journal of Applied Linguistics, 15(2), 119-144. https://doi.org/10.1111/j.1473-4192.2005.00084.x

Lin, A. M. Y. (1999). Doing-English-Lessons in the Reproduction or Transformation of Social Worlds? Tesol Quarterly, 33(3), 393-412. https://doi.org/10.2307/3587671

Lipovsky, C., \& Mahboob, A. (2010). Students'appraisal of their native and non-native english-speaking teachers. WATESOL NNEST Caucus Annual Review, 1, 119-154.

Lowe, R. J., \& Kiczkowiak, M. (2016). Native-speakerism and the complexity of personal experience: A duoethnographic study. Cogent Education, 3(1), N.PAG-N.PAG. https://doi.org/10.1080/2331186X.2016. 1264171

Luke, A. (2011). Critical Literacy and Second Langauge Learning. In E. HInkel (Ed.), Handbook of Research on Second Language Teaching and Learning (Vol. 2). New York: Routledge.

Mahboob, A. (2005). Beyond the native speaker in TESOL. In S. Zafar (Ed.), Culture, context, and communication (pp. 60-93). Abu Dhabi, United Arab Emirates: Center of Excellence for Applied Research and Training and the Military Language Institute.

Mahboob, A. (2010). The NNEST lens: Non native English speakers in TESOL: Cambridge Scholars Publishing.

Mahboob, A., \& Golden, R. (2013). Looking for native speakers of English: Discrimination in English language teaching job advertisements. Age, 3(18), 21.

Matsuda, A. (2016). Reconceptualising teacher qualification. In S. G. a. S. M. In Fiona Copland (Ed.), LETs and NESTs: Voices, Views and Vignettes (pp. 251). UK: Briths Council.

Matsuda, A., \& Matsuda, P. (2001). Autonomy and collaboration in teacher education: Journal sharing among native and nonnative English-speaking teachers. CATESOL Journal, 13(1), 109-121.

Maum, R. (2002). Nonnative-English-Speaking Teachers in the English Teaching Profession.

Maum, R. (2003). A comparison of native and nonnative English-speaking teachers' beliefs about teaching English as a second language to adult English language learners. University of Louisville, Louisville: KY.

Menard-Warwick, J. (2008). The Cultural and Intercultural Identities of Transnational English Teachers: Two Case Studies from the Americas. TESOL Quarterly: A Journal for Teachers of English to Speakers of Other 
Languages and of Standard English as a Second Dialect, 42(4), 617-640. https://doi.org/10.1002/j. 1545-7249.2008.tb00151.x

Morgan, B. (2004). Teacher identity as pedagogy: Towards a field-internal conceptualisation in bilingual and second language education. International Journal of Bilingual Education and Bilingualism, 7(2-3), 172-188. https://doi.org/10.1080/13670050408667807

Motha, S. (2006). Racializing ESOL Teacher Identities in U.S. K-12 Public Schools. TESOL Quarterly: A Journal for Teachers of English to Speakers of Other Languages and of Standard English as a Second Dialect, 40(3), 495-518. https://doi.org/10.2307/40264541

Motha, S. (2014). Race, empire, and English language teaching: Creating responsible and ethical anti-racist practice. Canada: Teachers College Press.

Motha, S., Jain, R., \& Tecle, T. (2012). Translinguistic identity-as-pedagogy: Implications for language teacher education. International Journal of Innovation in English Language Teaching and Research, 1(1), 13.

Moussu, M. (2002). English as a Second Language Students' Reactions to Nonnative English-Speaking Teachers. (Master of Arts), Brigham Young University, Utah, United Sates.

Moussu, M. (2006). Native and nonnative English-speaking English as a second language teachers: student attitudes, teacher self-perceptions, and intensive English administrator beliefs and practices. Thesis (Ph.D.). Purdue University, USA.

Moussu, M. (2010). Influence of Teacher-Contact Time and Other Variables on ESL Students' Attitudes Towards Native- and Nonnative-English-Speaking Teachers. Tesol Quarterly, 44(4), 746-768. https://doi.org/10.5054/tq.2010.235997

NEAS. (2017). NEAS Teacher Qualifications. Retrieved from https://bit.ly/2Vf751X

Norton, B. (2015). Identity, Investment, and Faces of English Internationally. Chinese Journal of Applied Linguistics, 38(4), 375-391. https://doi.org/10.1515/cjal-2015-0025

Oliver, R., Rochecouste, J., \& Nguyen, B. (2017). ESL in Australia - A checquered history. TESOL in Context, 26(1), 7-26. https://doi.org/10.21153/tesol2017vol26nolart700700

Paikeday, T. M. (1986). The native speaker is dead! World Englishes, 5(1), 109-110. https://doi.org/10.1111/ j.1467-971X.1986.tb00644.x

Park, G. (2012). "I Am Never Afraid of Being Recognized as an NNES": One Teacher's Journey in Claiming and Embracing Her Nonnative-Speaker Identity. Tesol Quarterly, 46(1), 127-151. https:/doi.org/ 10.1002/tesq.4

Pennycook, A. (1994). The cultural politics of English as an international language. New York: Longman.

Pennycook, A. (1995). English in the world/The world in English. In J. W. Tollefson (Ed.), Power and inequality in language education. Cambridge, UK: Cambridge University Press.

Pennycook, A. (1999). Introduction: Critical approaches to TESOL. Tesol Quarterly, 33(3), 329-348. https://doi.org/10.2307/3587668

Pennycook, A. (2004). Critical moments in a TESOL praxicum. Critical pedagogies and language learning, 327-345. https://doi.org/10.1017/CBO9781139524834.017

Pennycook, A. (2007). ELT and colonialism. In International handbook of English language teaching NY: Springer.

Pennycook, A. (2008). Critical applied linguistics and language education. In S. May, \& N. H. Hornberger (Eds.), Encyclopedia of Language and Education (2nd ed., Vol. 1, pp. 169-181): Springer US. https://doi.org/ 10.1007/978-0-387-30424-3_13

Phillipson, R. (1992a). Linguistic imperialism. Oxford:: Oxford England.

Phillipson, R. (1992b). ELT: the native speaker's burden? ELT Journal, 46(1), 12-18. https://doi.org/10.1093/ elt/46.1.12

Phillipson, R. (2016). Native-speakerism has Tragic Consequences. In S. G. a. S. M. Fiona Copland (Ed.), LETs and NESTs: Voices, Views and Vignettes (pp. 248-249). UK: British Council.

Piller, I. (2002). Passing for a native speaker: Identity and success in second language learning. Journal of sociolinguistics, 6(2), 179-208. https://doi.org/10.1111/1467-9481.00184 
Rampton, M. B. H. (1990). Displacing the 'native speaker': Expertise, affiliation, and inheritance. https://doi.org/10.1093/elt/44.2.97

Reis, D. (2010). Non-native English-speaking teachers and professional legitimacy: A sociocultural theoretical perspective on identity realization. In K. Johnson (Ed.): ProQuest Dissertations Publishing. https://doi.org/10.1515/ijsl.2011.016

Reves, T., \& Medgyes, P. (1994). The non-native english speaking EFL/ESL teacher's self-image: An international survey. System, 22, 353-367. https://doi.org/10.1016/0346-251X(94)90021-3

Rudolph, N. (2012). Borderlands and border crossing: Japanese professors of English and the negotiation of translinguistic and transcultural identity. In M. Martin-Beltran, B. Finkelstein, D. Imig, S. Klees, \& J. Turner (Eds.): ProQuest Dissertations Publishing.

Rudolph, N., Selvi, A. F., \& Yazan, B. (2015). Conceptualizing and confronting inequity: Approaches within and new directions for the "NNEST movement". Critical Inquiry in Language Studies, 12(1), 27-50. https://doi.org/10.1080/15427587.2015.997650

Said, E. W. (1985). Orientalism reconsidered. Race \& Class, 27(2), 1-15. https://doi.org/10.1177/03063968 8502700201

Samimy, K., \& Brutt-Griffler, J. (1999). To be a native or non-native speaker: Perceptions of 'non-native' students in a graduate TESOL program. In G. Braine (Ed.), Non-native educators in English language teaching (pp. 127-144). Mahwah, N.J.: L. Erlbaum Associates.

SEEK. (2017). Casual Language Educator. Retrieved from https://bit.ly/31OCtqz

Selinker, L. (1972). Interlanguage. IRAL-International Review of Applied Linguistics in Language Teaching, 10(1-4), 209-232. https://doi.org/10.1515/iral.1972.10.1-4.209

Selvi, A. F. (2010). All teachers are equal, but some teachers are more equal than others: Trend analysis of job advertisements in English language teaching. WATESOL NNEST Caucus Annual Review, 1(1), 155-181.

Selvi, A. F. (2016). Native or non-native English-speaking professionals in ELT:'That is the question!' or 'Is that the question?': Aims and Goals. In S. G. a. S. M. Fiona Copland (Ed.), LETs and NESTs: Voices, Views and Vignettes (pp. 248-249). UK: British Council.

Shin, H. (2006). Rethinking TESOL from a SOL's perspective: Indigenous epistemology and decolonizing praxis in TESOL. Critical Inquiry in Language Studies, 3(2-3), 147-167. https://doi.org/10.1080/15427587. 2006.9650844

Suárez, J. (2000). 'Native' and 'non-native': Not only a question of terminology Humanizing Language Teaching. Retrieved from www.hltmag.co.uk/nov00/martnov001.rtf

TESOL International Association. (2017). TESOL International Association. Retrieved from http://www.tesol.org/

Thomas, J. (1999). Voices from the periphery: Non-native teachers and issues of credibility. In G. Braine (Ed.), Non-native educators in English language teaching (pp. 5-13). Mahwah, NJ: Erlbaum. Retrieved from https://bit.ly/2E65tkb.

Varghese, M., Morgan, B., Johnston, B., \& Johnson, K. A. (2005). Theorizing Language Teacher Identity: Three Perspectives and Beyond. Journal of Language, Identity \& Education, 4(1), 21-44. https://doi.org/10.1207/ s15327701jlie0401_2

Vygotsky, L. S. (1978). Mind in society (M. Cole, V. John-Steiner, S. Scribner, \& E. Souberman, Eds.). In: Cambridge, MA: Harvard University Press.

Widdowson, H. (2003). Defining issues in English language teaching. Oxford University Press.

Widdowson, H. G. (1994). The ownership of English. Tesol Quarterly, 28(2), 377-389. https://doi.org/ $10.2307 / 3587438$

Wibawa, T., \& Xiao, B. (2018). Australian travellers teaching English overseas without qualifications cause alarm. ABC News. Retrieved from https://amp.abc.net.au/article/10220830 


\section{Copyrights}

Copyright for this article is retained by the author(s), with first publication rights granted to the journal.

This is an open-access article distributed under the terms and conditions of the Creative Commons Attribution license (http://creativecommons.org/licenses/by/4.0/). 